\title{
Developing Horizontal Subsurface Flow Constructed Wetland using Pumice and Chrysopogon zizanioides for Tannery Wastewater Treatment
}

Mekonnen Birhanie Aregu ( $\square$ mokebir16@gmail.com )

Dilla University https://orcid.org/0000-0002-4110-0345

Seyoum Leta Asfaw

Addis Ababa University

Mohammed Mazharuddin Khan

Addis Ababa University

Research

Keywords: Tannery wastewater, Pumice, Constructed wetland, Chrysopogon zizanioides

Posted Date: June 16th, 2021

DOI: https://doi.org/10.21203/rs.3.rs-358265/v2

License: (c) (1) This work is licensed under a Creative Commons Attribution 4.0 International License. Read Full License 


\section{Abstract}

Background: High-strength wastewater defined by elevated levels of hazardous pollutants measured in BOD, heavy metals, nutrients and other toxic substances. This kind of wastewater discharged to water body without treatment from different industrial sectors that adversely affects aquatic environment and downstream water consumers. The general objective of this study is to investigate efficient substrate with selected plant type for constructed wetland to remove hazardous pollutants from tannery wastewater. This study was conducted at Modjo town from 2016 to 2018 . Plug flow experimental study design was carried out. The substrate (Pumice) was collected around the study area and chemical characteristics were determined. Chrysopogon zizanioides was planted and grown for five months before running tannery wastewater for the treatment. The composite wastewater was introduced to the constructed wetland from Modjo leather industry, Ethiopia. The physicochemical analysis of the sample wastewater was done before and after treatment at four different hydraulic retention time.

Results: Characterization of the untreated tannery wastewater revealed that the mean concentration of $\mathrm{BOD}_{5}, \mathrm{COD}_{1} \mathrm{TSS}, \mathrm{PO}_{4}-\mathrm{P}, \mathrm{TP}, \mathrm{NO}_{3}-\mathrm{N}, \mathrm{TN}$ and total chromium were $1641 \pm 373.6,6953.33 \pm 339.4,1868 \pm 863.1,88.06 \pm 40.8,144.53 \pm 20.8,116.66 \pm 26.6,650.33 \pm 93.6$ and $18.33 \pm 6.7 \mathrm{mg} / \mathrm{l}$ respectively beyond the permissible limits. The maximum removal efficiency of the constructed wetland in pumice bed revealed that BOD 5 at HRT 7 and 9 days (96.42\%, 96.30\%), COD at HRT 5 and 7 days (96.76\%, 96.91\%), $\mathrm{NO}_{3}-\mathrm{N}$ at HRT 5 and 7 days (99.99\%, 99.68\%), TN (98.67\%, 99.00\%), PO $-\mathrm{P} \mathrm{HRT} \mathrm{7and} 9$ days $(96.97 \%, 100 \%)$, TP at HRT 5 and 7 days (94.79\%, 96.17\%) and total Chromium at HRT 5 and 7 days (98.36\%, 98.91\%) respectively. Whereas, the removal efficiency of constructed wetland bed with gravel substrate used as a control subject with similar condition to pumice showed lower performance. The result between pumice and gravel bed was tested for their significance difference using two sample t-test statistics. Based on the test statistics, the pumice substrate perform better than the gravel significantly at $95 \%$ confidence interval, $p$-value $=0.01$.

Conclusion: Pumice substrate and Chrysopogon zizanioides have a potential ability to remove hazardous pollutants from tannery wastewater in horizontal subsurface constructed wetlands.

\section{Background}

Industrial wastewater is the most common source of environmental pollution in the current situation. The discharge of high strength wastewaters with high concentration of nutrients and heavy metals from industrial sectors can have harmful consequences on the ecological balance and ecosystem function of the receiving environment as well as the public health of downstream end-users of the polluted water sources (Asamudo et al., 2005).

Tanning is one of the oldest industries in the world. During ancient times, tanning activities were organized to meet the local demands of leather footwear, drums and musical instruments. With the growth of population, the increasing requirement of leather and its products led to the establishment of large commercial tanneries. Two methods are adopted for tanning of raw hide/skin, vegetable tanning, and chrome tanning. Tanneries are typically characterized as pollution intensive industrial complexes which generate widely varying, high-strength wastewaters. Nearly 30 $\mathrm{m}^{3}$ of wastewater is generated during processing of one tone of raw skin/hide (Suthanthararajan et al., 2004).

Tannery operation consists of converting of the raw hide or skin into leather which consume huge amount of water in several stages, generating an enormous amount of liquid effluents which are hazardous to the environment to which they are discharged, consequently, make it as a potentially pollution intensive industry. Tannery effluents again compromise the physical, chemical and biological properties of aquatic environment. Apart from the most toxic heavy metals like Chromium ( $\mathrm{Cr}$ ) chemical impurities of tannery effluents mostly includes the following dissolved substances such as inorganic salt cations ( $\mathrm{Fe}, \mathrm{Zn}, \mathrm{Cu}, \mathrm{Ca}, \mathrm{Na}$, etc.); anions such as $\mathrm{SO}_{4}{ }^{2-}, \mathrm{NO}_{3}{ }^{-}, \mathrm{PO}_{4}{ }^{3-}$ and parameters such as, Biochemical Oxygen demand (BOD), Chemical Oxygen Demand (COD), Total Suspended Solid (TSS), Total Dissolved Solid (TDS) etc (Kawser et al., 2011). Therefore treating tannery wastewater using natural adsorbents is very important to protect the surrounding environment.

In Ethiopia currently, there are more than 30 tannery industries in operation. Among them the majority found in Oromia region especially Mojo town and around six established in the capital city Addis Ababa. These tanneries have 153,650 sheep and goat skin soaking capacity and 9,725 cowhides soaking capacity per day. Together they also employ 4577 persons (UNIDO, 2012).

Leather is one of the most important export item of Ethiopia earning foreign exchange. On the other hand, the leather tanning industry has been recognized as one of the main causes of water and environmental pollution. With the high adoption of chrome tanning in most of the tanning industries in the country, efficient methods of chromium, nutrients and other pollutant removal from tannery wastewater are important to attain environmental quality standards.

Conventional wastewater treatment processes such as activated sludge and biofilms are used seldom in Africa including Ethiopia due to lack of energy and financial resources. Therefore in this case constructed wetland is sustainable option for industrial wastewater treatment. Because, constructed wetlands can provide an energy-efficient, cost-effective, and low maintenance alternative to conventional wastewater treatment technologies (Kadlec and Knight, 1996). They also have additional benefits that include creating habitat for plants and wildlife and an aesthetic green space in communities.

Kivaisi (2001) assured that there is potential for the development of CWs in developing countries like Ethiopia. The author points out this to the location of many developing countries in warm tropical and sub-tropical climates (Ethiopia located in Tropics), which are favorable to higher biological 
activity and productivity, and hence better treatment performance.

Compared with the conventional wastewater treatment system currently in use the constructed wetland has its own advantage. Constructed wetlands are natural wastewater treatment systems that typically have lower construction, operation and maintenance costs than conventional mechanical treatment systems. Constructed wetlands are therefore cost effective, eco-friendly and technically feasible approach for treating industrial wastewater including high strength tannery wastewater.

Even though literature cannot found in Ethiopia on the cost comparison of constructed wetland and conventional wastewater treatment, Study conducted in Ireland by Reddy (2004) showed that the cost of a typical constructed wetland cheaper by $30 \%$ than conventional treatment methods of the same size considering the lifespan and replacement value of the wetland. The above case studies confirmed that the maintenance cost for constructed wetlands was eight times lower than the conventional treatment system. Furthermore, operation and maintenance require only periodic rather than continues.

The result of another study indicated that the total annual cost for waste stabilization pond was $21 \%$ more than that of the constructed wetlands (Tomokin, 2000). Based on the overall results of the treatment performance and costs, these researchers concluded that the application of constructed wetlands can be considered both technically and economically viable option for wastewater treatment.

Conventional wastewater treatment systems contains energy demanding and mechanical treatment components which require substantial investment and high operating costs. Experience has shown that existing wastewater treatment systems in most of the developing countries failed to treat wastewater effectively it is because of high operating and maintenance costs, lack of local expertise and poor institutional governance. Compared to conventional treatment systems, constructed wetlands are low cost, easy to operate and maintain, and have a strong prospective for application in developing countries (Vymazal, 2010).

On the other hand, adsorption has been identified as one of the most promising mechanism for removal of dissolved heavy metal fractions and nutrients from wastewater. Although commercial adsorbents are available for use in adsorption, they are very expensive, resulting in various new lowcost adsorbents being studied by researchers. Babel and Kurniawan (2003), reviewed the technical feasibility of various low-cost adsorbents for heavy metals removal from wastewater and concluded that the use of low-cost adsorbents may contribute to the sustainability of the surrounding environment and offer promising benefits for commercial purpose in the future. Therefore identifying potentially efficient substrate for constructed wetland as an adsorbent is critical for proper practice of environmental management by tanning industries.

\section{Materials And Methods}

Study Area and Period: This study was conducted in Oromia region east Showa zone, Modjo town at Modjo tanning industry PLC (Fig.1) from 2016 to 2018.

Study Design: Plug flow experimental study design was carried out to determine the efficiency of pumice substrate and Chrysopogon zizanioides plant species in horizontal subsurface constructed wetland to remove hazardous pollutants from high-strength tannery wastewater.

\section{Experimental materials, Design and setup Establishments}

Pumice was collected from volcanic cones of refit valley area of Oromia region east showa zone ( $8^{\circ} 28^{\prime} 36^{\prime \prime} \mathrm{N}$ and 39¹4'29"E), Ethiopia $20-30 \mathrm{~km}$ far from Modjo Tannery $\left(8^{\circ} 35^{\prime} 13^{\prime \prime} \mathrm{N}\right.$ and $\left.39^{\circ} 07^{\prime} 23^{\prime \prime} \mathrm{E}\right)$ approximately $70 \mathrm{~km}$ East of Addis Ababa (Fig. 1). The chemical characteristics of this substrate was determined by using XRF analysis.

The plant (Chrysopogon zizanioides) was collected from Holeta Agricultural research institute and transported to Modjo tanning industry. It was planted in the horizontal subsurface constructed wetland and grown for five months before running high-strength wastewater for the treatment.

The horizontal subsurface constructed wetland was installed at Modjo tanning industry compound for the treatment of tannery wastewater (Fig. 2). The treatment system consists of: a primary screening and a grit removal tank; sedimentation tank for sludge settling and equalization tank connected with horizontal subsurface flow constructed wetland (HSSFCW), with an effective volume of $1.92 \mathrm{~m}^{3}$ each which is a length of $4 \mathrm{~m}$, width of $0.8 \mathrm{~m}$ and effective depth of $0.6 \mathrm{~m}$.

The CWs are filled with medium-sized gravel, ranging in size from 6 to $20 \mathrm{~mm}$ as a control and pumice $10-25 \mathrm{~mm}$ grain size substrate vegetated with Chrysopogon zizanioides in separate constructed wetland cell with similar size and dimensions (Fig 3). The pumice substrate was crushed and graded. Effective size was determined by using standard sieve. Based on the analysis the effective size $(E S)\left(d_{10}\right)$ of the media was $1.5-4.5$ and the uniformity coefficient $(U C)\left(d_{60} / d_{10}\right)$ was $3.5-4$.

The raw wastewater is fed into a sedimentation tank from the factory after 24 hour retention time pumped to the equalization tank with volume of 5000 liter then the $\mathrm{CWs}$ fed from this tank through $3 / 4^{\text {th }}$ inch pipe with control valve for each cell. Performance of this constructed wetland was 
recorded for two years based on four different hydraulic retention time (3, 5, 7 and 9 days).

\section{Sample Collection and Laboratory Analysis}

The on-site measurement of the physicochemical parameters was undertaken. The physicochemical analysis of wastewater samples was done before and after the treatment with the two different hydraulic retention time, using standard methods. The analytical parameters were $\mathrm{pH} \mathrm{BOD}_{5}, \mathrm{COD}_{\text {, }}$ Ammonium N, Nitrite N, Nitrate N, Total N, Phosphate, Total P, TSS, TDS, Salinity and Chromium. On-site measurement of the wastewater like temperature, $\mathrm{pH}$ and $\mathrm{DO}$ were carried out at the site in the tannery environmental quality control laboratory using portable $\mathrm{pH}$ meter (Wagtech International N374, M128/03IM, USA) and DO meter (Hach P/N HQ30d, Loveland. CO, USA) for Dissolved oxygen and temperature.

COD, Ammonium-nitrogen, Nitrite-nitrogen, Nitrate-nitrogen, Phosphate, Chloride, Sulfide and Sulfate were measured by using spectrophotometer (Hach model DR/3900 portable spectrophotometer, Germany) according to Hach instructions. BOD 5 and total Chromium were analyzed using BOD sensor and inductive stirring system AQUA LYTIC model type ET618-4 and Flame Atomic Absorption Spectrophotometer (AAS), (model AAS NOUA-400, Germany) respectively. Total suspended solids (TSS) were determined according to the Standard Methods for the Examination of Water and Wastewater gravimetric method. Heavy metal uptake capacity of the plant and adsorption potential of the pumice were determined by Ash-Modified AOAC 923.03 and Minerals-Modified AOAAC 985.35 (APHA, 2005).

The removal efficiency of the filter media for the selected parameters were calculated as:

$\%$ removal $₫ \mathrm{Ci}-\mathrm{Cf} / \mathrm{Ci} \times 100$

Where $\mathrm{C}_{\mathrm{i}}$ is the parameter concentration in the untreated wastewater and $\mathrm{C}_{\mathrm{f}}$ is the parameter concentration in the treated wastewater.

Statistical Data Analysis: Mean and standard deviations were calculated to estimate the concentration of each parameter of the samples. The hypothesis has been tested by two sample t-test using R statistical software: R version 3.2.2 (2015-08-14), Platform: x86_64-w64-mingw32/x64 (64-bit) and Originlab pro 2017 to determine whether an observed difference between the means of the groups is statistically significant or not, based on the two hydraulic retention time.

Data Quality Management: To assure quality of the data by minimizing the errors the following measures had been undertaken: Apparatuses were calibrated; expiry date of reagents had been checked before starting the real analysis and standard control also prepared. Each test had been triplicated.

\section{Result And Discussion}

\section{Physicochemical Characteristics of Modjo Tannery Wastewater}

The raw wastewater was taken from Modjo tannery for physicochemical analysis. Based on this investigation the mean concentration of selected physicochemical parameters were presented at Table 1.

Table 1 Characteristics of Modjo Tannery Raw Wastewater

\begin{tabular}{|c|c|c|}
\hline Parameters (mg/l) & Mean value & Range \\
\hline $\mathrm{pH}$ & $10.166 \pm 2.02$ & $8-12$ \\
\hline $\mathrm{BOD}_{5}$ & $1641 \pm 373.6$ & $1243-1984$ \\
\hline COD & $6953.333 \pm 339.4$ & $6593-7267$ \\
\hline $\mathrm{NH}_{4}-\mathrm{N}$ & $253.3333 \pm 11.6$ & $240-261$ \\
\hline $\mathrm{NO}_{2}-\mathrm{N}$ & $1.913333 \pm 0.12$ & 1.77-1.99 \\
\hline $\mathrm{NO}_{3}-\mathrm{N}$ & $116.6667 \pm 26.6$ & $94-146$ \\
\hline TN & $650.3333 \pm 93.6$ & $546-727$ \\
\hline $\mathrm{PO}_{4}-\mathrm{P}$ & $88.06667 \pm 40.8$ & $46.5-128$ \\
\hline TP & $144.5333 \pm 20.8$ & $128.6-168$ \\
\hline TSS & $1868 \pm 863.1$ & $1217-2847$ \\
\hline TDS & $5877.3 \pm 2294.8$ & $3250-7489$ \\
\hline $\mathrm{TCr}$ & $18.33 \pm 6.7$ & $14-26$ \\
\hline
\end{tabular}


This study revealed that the mean concentration of $\mathrm{BOD}_{5}, \mathrm{COD}$ and TSS were $1641 \pm 375.6,6953 \pm 339.4$ and $1868 \pm 863.1 \mathrm{mg} / \mathrm{l}$ respectively (Table 1 ). This result is basically similar to different studies in Ethiopia with slight difference for different parameters for example a study done at the same tannery industry indicated that the mean concentration of COD was laid between 7950 to $15240 \mathrm{mg} / \mathrm{l}$ with the mean of $11123 \pm 563.9 \mathrm{mg} / \mathrm{l}$ (Seyoum Leta, et al., 2003). Another study also undertaken with same tannery wastewater showed that the mean concentration of $\mathrm{BOD}_{5} \mathrm{was} 1054 \pm 448 \mathrm{mg} / \mathrm{I}$ (Tadesse Alemu and Seyoum Leta, 2015) and the concentration of total suspended solid was found from 1217 to 2847 (Table 3.1 ) this is a bit greater than some studies for instance a study done in India indicated that $1244 \mathrm{mg} / \mathrm{l}$ (Tamal et al., 2010).

Nutrients like orthophosphate, ammonium, nitrite and nitrate concentration of Modjo tannery were characterized in this study, the result revealed that $88 \pm 40.8,253.3 \pm 11.6,1.9 \pm 0.12,116.7 \pm 26.6 \mathrm{mg} / \mathrm{l}$ respectively. This result is comparable to a study done by Sivakumar et al., (2015) which indicates the concentration of nitrate in untreated tannery effluent was $116 \mathrm{mg} / \mathrm{l}$. The result of ammonium is also similar to that of the results done at Bahir Dar tannery wastewater characterization (96-420 mg/I) (Aseessefa and Ayalew, 2014). According to Arasappan and Kalyanaraman (2015), the nitrite concentration of untreated tannery wastewater was $1.3 \mathrm{mg} / \mathrm{l}$ almost parallel to this study finding which accounts $1.9 \pm 0.12 \mathrm{mg} / \mathrm{l}$ (Table 1 ). Some variation have been seen in some parameters. This variation may be due to the utilization of chemicals for different purposes and different tanning activities among tanneries.

In terms of chromium concentration, Modjo tannery comprised $18.33 \pm 6.7 \mathrm{mg} / \mathrm{l}$ is similar to other different results presented from same tannery wastewater by Tadesse Alemu et al. (2016) the mean influent wastewater to the constructed wetland was $18.67 \mathrm{mg} / \mathrm{l}$. Likewise a variation exists in values of physicochemical parameters in general like $\mathrm{BOD}_{5}, \mathrm{COD}$, TSS, phosphate, sulfide, sulfate, etc. in every tannery wastewater characteristics, this may be because of different tanning process, methods, technology and raw material utilization by various tanning industries.

Tannery Wastewater Treatment Efficiency of Horizontal Subsurface Flow Constructed Wetland with Pumice Substrate Planted with Chrysopogon zizanioides(CZ)

The pollutant removal efficiency of horizontal subsurface constructed wetland under this investigation was high this may be due to the high adsorption capacity of pumice and the uptake potential of Chrysopogon zizanioides from tannery wastewater. The characteristics of tannery wastewater after treatment was alongside with the standard guideline value of the Ethiopian environmental protection authority and WHO irrigation water quality standard (Table 2).

\section{$\mathrm{BOD}_{5}, \mathrm{COD}$ and TSS Removal Efficiency of HSSFCW with Pumice Substrate and Planted with Chrysopogon Zizanioides}

The three important pollutant of the tannery wastewater were analyzed before and after treatment of four hydraulic retention time, based on the finding the final effluent concentration of $\mathrm{BOD}_{5}, \mathrm{COD}$ and TSS in $\mathrm{mg} / \mathrm{I}$ were $(273 \pm 91,532.50 \pm 177.5$ and $99.72 \pm 80.93)$ for 3 days HRT, (74 $\pm 2,225.41 \pm 11.13$ and $79 \pm 13.53)$ for 5 days HRT, $(58.67 \pm 6.5,214.67 \pm 32.33$ and $80 \pm 4.58)$ for 7 days HRT and $(60.67 \pm 4.93,234.67 \pm 38.79$ and $74 \pm 21.65)$ for 9 days HRT (Table 2). Both BOD and COD result of 5, 7 and 9 HRT were met the standard value of WHO water quality for irrigation and EEPA (200 and 500 $\mathrm{mg} / \mathrm{l}$ ) but they are beyond the standard at hydraulic retention time of 3 days this is because of the time shortage to degrade organic matter. In all the allotted hydraulic retention time TSS was not achieved good result as compared to the Both WHO and EEPA guideline (50mg/I) (EEPA 2003;WHO 2011).

Table 2 Characteristics of Treated Wastewater by HSSFCW with Pumice Substrate and CZ at Different HRT 


\begin{tabular}{|c|c|c|c|c|c|c|}
\hline \multirow[t]{2}{*}{ Parameters } & \multirow{2}{*}{$\begin{array}{l}\text { Influent (mg/L, except for } \mathrm{pH}, \mathrm{EC} \text { and } \\
\text { salinity) }\end{array}$} & \multicolumn{4}{|c|}{ Effluent Conc. at Different HRT( $\mathrm{mg} / \mathrm{L}$, except pH, EC \& salinity) } & \multirow{2}{*}{$\begin{array}{l}\text { EEPA \&WHO } \\
\text { irrigation WQS }\end{array}$} \\
\hline & & 3 days & 5 days & 7 days & 9 days & \\
\hline $\mathrm{BOD}_{5}$ & $1641 \pm 373.55$ & $273 \pm 91$ & $74 \pm 2$ & $58.67 \pm 6.5$ & $60.67 \pm 4.93$ & 200 \\
\hline COD & $6953.33 \pm 339.41$ & $532.50 \pm 177.5$ & $225.41 \pm 11.13$ & $214.67 \pm 32.33$ & $234.67 \pm 38.79$ & 500 \\
\hline $\mathrm{NH}_{4}-\mathrm{N}$ & $253.33 \pm 11.6$ & $26.83 \pm 2.93$ & $5.00 \pm 4.36$ & $4.67 \pm 1.53$ & $6.83 \pm 1.44$ & 30 \\
\hline $\mathrm{NO}_{3}-\mathrm{N}$ & $116.66 \pm 26.63$ & $10.83 \pm 2.75$ & $0 \pm 0$ & $0.37 \pm 0.15$ & $0.57 \pm 0.21$ & 10 \\
\hline TN & $650.33 \pm 93.62$ & $42 \pm 15.72$ & $8.67 \pm 5.7$ & $6.50 \pm 1.32$ & $9.33 \pm 2.1$ & 60 \\
\hline $\mathrm{PO}_{4}-\mathrm{P}$ & $88.06 \pm 40.77$ & $6.33 \pm 2.1$ & $3.04 \pm 1$ & $2.67 \pm 1.26$ & $0 \pm 0$ & 5 \\
\hline TP & $144.53 \pm 20.75$ & $19.67 \pm 3.05$ & $7.53 \pm 2.33$ & $5.53 \pm 0.5$ & $83.87 \pm 11.37$ & 10 \\
\hline TSS & $1868 \pm 863.1$ & $99.72 \pm 80.93$ & $79 \pm 13.53$ & $80 \pm 4.58$ & $74 \pm 21.65$ & 50 \\
\hline TDS & $5877.3 \pm 2294.77$ & $1504.97 \pm 1286.16$ & $1279 \pm 75$ & $768.67 \pm 45.54$ & $798 \pm 17.43$ & 2100 \\
\hline $\mathrm{TCr}$ & $18.33 \pm 6.66$ & $0.88 \pm 0.03$ & $0.30 \pm 0.1$ & $0.20 \pm 0.1$ & $0.35 \pm 0.13$ & 2 \\
\hline
\end{tabular}

The removal efficiency of this horizontal flow subsurface constructed wetland filled with pumice substrate and planted with Chrysopogon zozanioides was high for the purification of tannery wastewater considering the three polluting agents with specific hydraulic retention time. During the first 3 and 5 days retention time BOD $_{5}$, COD and TSS were reduced by $(83.36 \%, 92.34 \%$ and $94.66 \%)$ and $(95.49 \%, 96.76 \%$ and $95.77 \%)$ respectively. After the second 7 and 9 days retention time also it reduced by $(96.42 \%, 96.91 \%$ and $95.72 \%)$ and $(96.30 \%, 96.62 \%$ and $96.02 \%)$ respectively (Table 3 ).

The result achieved due to the activities of the microorganisms and the networked and spongy tuft roots of the plant to make comfortable environment for the growth of the organism in addition to absorption. The aerobic condition in the superficial wetland bed and anaerobic condition in the bottom allow for efficient removal of organic pollutants and the filtration of the wastewater is the main reason for the removal of suspended solids. A vertical subsurface wetland planted with Scirpus Alternifolios and red ferralitic soil substrate was evaluated by scholars for its wastewater purification capacity and reported as BOD, COD and TSS were reduced by $(84.9 \%, 89.8 \%$ and $98.1 \%)$ respectively (Villara et al., 2012), the result is almost similar to this investigation especially with the first 3 and 5 hours retention time.

Table 3 Efficiency of HSSFCW with Pumice Substrate and CZ at Different HRT

\begin{tabular}{|c|c|c|c|c|c|c|c|c|c|}
\hline \multirow[t]{3}{*}{ Parameters } & \multirow{3}{*}{$\begin{array}{l}\text { Influent } \\
\text { conc. }\end{array}$} & \multicolumn{8}{|c|}{ Percentage Removal at Different HRT } \\
\hline & & \multicolumn{2}{|l|}{3 days } & \multicolumn{2}{|l|}{5 days } & \multicolumn{2}{|l|}{7 days } & \multicolumn{2}{|l|}{9 days } \\
\hline & & $\begin{array}{l}\text { Mean Conc. } \\
(\mathrm{mg} / \mathrm{l})\end{array}$ & $\begin{array}{l}\% \\
\text { Removal }\end{array}$ & $\begin{array}{l}\text { Mean Conc. } \\
(\mathrm{mg} / \mathrm{l})\end{array}$ & $\begin{array}{l}\% \\
\text { Removal }\end{array}$ & $\begin{array}{l}\text { Mean Conc. } \\
(\mathrm{mg} / \mathrm{l})\end{array}$ & $\begin{array}{l}\% \\
\text { Removal }\end{array}$ & $\begin{array}{l}\text { Mean Conc. } \\
(\mathrm{mg} / \mathrm{l})\end{array}$ & $\begin{array}{l}\% \\
\text { Removal }\end{array}$ \\
\hline $\mathrm{BOD}_{5}$ & $1641 \pm 373.55$ & $273 \pm 91$ & 83.36 & $74 \pm 2$ & 95.49 & $58.67 \pm 6.5$ & 96.42 & $60.67 \pm 4.93$ & 96.30 \\
\hline COD & $\begin{array}{r}6953.33 \\
\pm 339.41\end{array}$ & $532.50 \pm 177.5$ & 92.34 & $225.41 \pm 11.13$ & 96.76 & $214.67 \pm 32.33$ & 96.91 & $234.67 \pm 38.79$ & 96.62 \\
\hline $\mathrm{NH}_{4}-\mathrm{N}$ & $253.33 \pm 11.6$ & $26.83 \pm 2.93$ & 89.41 & $5.00 \pm 4.36$ & 98.03 & $4.67 \pm 1.53$ & 98.16 & $6.83 \pm 1.44$ & 97.30 \\
\hline $\mathrm{NO}_{3}-\mathrm{N}$ & $\begin{array}{l}116.66 \\
\pm 26.63\end{array}$ & $10.83 \pm 2.75$ & 90.72 & $0 \pm 0$ & 100 & $0.37 \pm 0.15$ & 99.68 & $0.57 \pm 0.21$ & 99.51 \\
\hline TN & $\begin{array}{l}650.33 \\
\pm 93.62\end{array}$ & $42 \pm 15.72$ & 93.54 & $8.67 \pm 5.7$ & 98.67 & $6.50 \pm 1.32$ & 99.00 & $9.33 \pm 2.1$ & 98.56 \\
\hline $\mathrm{PO}_{4}-\mathrm{P}$ & $88.06 \pm 40.77$ & $6.33 \pm 2.1$ & 92.81 & $3.04 \pm 1$ & 96.55 & $2.67 \pm 1.26$ & 96.97 & $0 \pm 0$ & 100 \\
\hline TSS & $1868 \pm 863.1$ & $99.72 \pm 80.93$ & 94.66 & $79 \pm 13.53$ & 95.77 & $80 \pm 4.58$ & 95.72 & $74 \pm 21.65$ & 96.04 \\
\hline $\mathrm{TCr}$ & $18.33 \pm 6.66$ & $0.88 \pm 0.03$ & 95.20 & $0.30 \pm 0.1$ & 98.36 & $0.20 \pm 0.1$ & 98.91 & $0.35 \pm 0.13$ & 98.09 \\
\hline
\end{tabular}


The plant (Chrysopogon zizanioides) used in this study possesses unique characteristics suitable for wastewater purification. Now a days various research findings showed its exceptional ability to absorb and to tolerate extreme levels of nutrients, to consume large quantities of water in the process of producing a massive biomass growth. These attributes indicated that this plant is highly suitable for treating high strength wastewater from different industries like tanning industries. In addition to the plant type, selection of best efficient substrate based on the selection criteria including its chemical composition is important for effective application of horizontal subsurface flow constructed wetland for the treatment of high strength industrial wastewater.

The main nutrient component concentrations like $\mathrm{NH}_{4}-\mathrm{N}, \mathrm{NO}_{3}-\mathrm{N}, \mathrm{TN}, \mathrm{PO}_{4}-\mathrm{P}$ and TP in Modjo tannery wastewater were determined before and after treatment using this horizontal subsurface constructed wetland to evaluate its treatment performance at four different hydraulic retention time. In the final effluent, the concentration of $\mathrm{NH}_{4}-\mathrm{N}, \mathrm{NO}_{3}-\mathrm{N}, \mathrm{TN}, \mathrm{PO}_{4}-\mathrm{P}$ and $\mathrm{TP}$ in $\mathrm{mg} / \mathrm{l}$ become $(26.83 \pm 2.93,10.83 \pm 2.75,42 \pm 15.72,6.33 \pm 2.1$ and $19.67 \pm 3.05)$ at 3 days HRT, $(5.00 \pm 4.36,0 \pm 0,8.67 \pm 5.7,3.04 \pm 1$ and $7.53 \pm 2.33)$ at 5 days HRT, $(4.67 \pm 1.53,0.37 \pm 0.15,6.50 \pm 1.32,2.67 \pm 1.26$ and $5.53 \pm 0.5)$ at 7 days HRT and $(6.83 \pm 1.44,0.57 \pm 0.21,9.33 \pm 2.1,0 \pm 0$ and $83.87 \pm 11.37)$ at 9 days HRT respectively (Table 2$)$.

When the result finding evaluated with the standard guideline value of WHO water quality standard and EEPA at different hydraulic retention time, $\mathrm{NH}_{4}-\mathrm{N}$ and $\mathrm{TN}$ were under the maximum permitable limit at all retention time and $\mathrm{NO}_{3}-\mathrm{N}$ and $\mathrm{PO}_{4}-\mathrm{P}$ were met the specified limit value at 5,7 and 9 days retention time only. But TP removal was good only at 5 and 7 days retention time. Therefore contact time of 5 days and greater are efficient retention time for the removal of major nutrients from tannery wastewater using horizontal subsurface constructed wetland filled with pumice substrate and planted with Chrysopogon zizanioides. Substrate composition, plant type and some microorganisms in the constructed wetland were play great role for the reduction of those nutrient components.

As various scholars reported, the removal of pollutants from wastewater are achieved by different mechanisms like sedimentation, filtration, chemical precipitation, adsorption, microbial interactions, and uptake of vegetation. The nutrient removal efficiency of this subsurface constructed wetland was generally effective. The maximum removal efficiency was seen at 5, 7 and 9 days retention time. The minimum (89.41\%) and maximum (98.16\%) of $\mathrm{NH}_{4}-\mathrm{N}$ removal efficiency was achieved at 3 and 7 days retention time respectively. Almost all of $\mathrm{NO}_{3}-\mathrm{N}$ also removed after 5 days treatment, more than $93.5 \%$ of TN was removed, $\mathrm{PO}_{4}-\mathrm{P}$ and TP were also effectively removed in this constructed wetland, a minimum of $92.81 \%$ at 3 days HRT and maximum of $100 \%$ at 9 days HRT of $\mathrm{PO}_{4}-\mathrm{P}$ was removed likewise TP from $41.97 \%$ at 9 days HRT up to $96.17 \%$ at 7 days $\mathrm{HRT}$ was removed (Figure 4).

This effective result was seen mainly because of the adsorption capacity of the substrate pumice and uptake potential ability of the plant. Especially pumice is effective to remove phosphate since it contains sufficient amount of aluminum and iron that favors for the removal of phosphorus (Villara et al., 2012). This study results again shows that the same trend to a study done by Nese and Ennil (2004) that indicates more than $95 \%$ nitrate removal efficiency from aqueous solution by adsorption mechanism.

On the other hand Chrysopogon zizanioides has high level of tolerance for high strength wastewater and very effective in removing pollutants from landfill leachates, particularly N and P. Nitrogen and Phosphorus absorption is also expedited because roots have direct exposure to effluents (Xia et al., 2000). Another study report which could support this findings also indicated that, the vetiver system is based on the use of vetiver grass (Chrysopogon zizanioides), which was first recognized early in the 1990s for having "super absorbent" characteristics suitable for the treatment of wastewater and leachate generated from landfill (Truong and Stone, 1996).

The efficiency of this constructed wetland in this pilot study to remove most of the hazardous pollutants from tannery wastewater was excellent. The reason may be due to the cumulative effect of the plant's ability and the substrate potential. The use of plants for wastewater treatment is not a new fashion. But the issue is how to improve pollutant removal efficiency. For example a project was done to examine the phytoremediation potential of water hyacinth (Eichhornia crassipes), water lettuce (Pistia stratiotes) and Vetiver (chrysopogon zizanioides) for the removal of Total dissolved solids from brine solution of textile industry by shallow pond system. The result reported after 10 days of operational period, water hyacinth showed maximum removal of $55.6 \%$ on 6th day, $48.7 \%$ using water lettuce on 7th day and $39.6 \%$ on 3rd day under Vetiver treatment system (Abinaya et al., 2018). Another study also was carried on constructed wetland to treat an aquaculture effluent using four species, Cyperus giganteus Vahl, Typha domingensis Pers., Pontederia cordata L. e Eichhornia crassipes in Brazil, in this study the constructed wetland perform $85.5 \%$ removal of total dissolved solid (Travaini and Sipauba, 2012).

\section{Chromium Removal Efficiency of HSSFCW with Pumice Substrate and Planted with Chrysopogon zizanioides}

Chromium is a toxic heavy metal which is found in tannery wastewater and causes serious environmental problem. Constructed wetland recently used for the removal of wastewater pollutants including heavy metals like chromium, the result of this investigation presents the chromium removal efficiency of horizontal subsurface flow constructed wetland from tannery wastewater. Based on the finding the concentration of total chromium in the tannery wastewater effluent after 3 and 5 days treatment time was $(0.88 \pm 0.03 \mathrm{mg} / \mathrm{l}$ and $0.30 \pm 0.1 \mathrm{mg} / \mathrm{l})$ respectively and this concentration further reduced to $0.20 \pm 0.1 \mathrm{mg} / \mathrm{l}$ and $0.35 \pm 0.13 \mathrm{mg} / \mathrm{l}$ after 7 and 9 days retention time respectively (Table 2 ). The effluent concentration at all retention time was under the standard guideline value of $2 \mathrm{mg} / \mathrm{l}$ set by WHO. 
The total chromium removal efficiency of this constructed wetland with pumice substrate and Chrysopogon zizanioides was calculated and become $95.20 \%, 98.36 \%, 98.91 \%$ and $98.09 \%$ at 3,5,7 and 9 days retention time respectively (Figure 5). In previous study it was observed that through increasing contact time, the removal efficiency of chromium in predetermined optimum dose of substrate powder increased significantly from $73.28 \%$ to $86.63 \%$ (Masoud et al., 2015). In this investigation the chromium adsorption capacity of pumice was analyzed, the result showed that $58.15 \mathrm{mg}$ of total chromium was adsorbed per one kilogram of pumice substrate. This result is similar to the previous research finding on phytoremediation of chromium by model constructed wetland which accounts $97-99.6 \%$ at all system of the constructed wetland with different plant species (Catherine et al., 2006).

The mechanism of heavy metals removal in horizontal subsurface constructed wetlands is a combination of different processes mainly physicochemical and biological which includes filtration, sedimentation, straining on the substrate, plant uptake, and precipitation as insoluble forms (Kadlec and Wallace, 2009). The most important reaction zone in constructed wetlands is the root zone (rhizosphere) where physicochemical and biological processes take place (Stottmeister et al., 2003). For this reason, this high chromium removal efficiency was achieved because of the metal adsorption potential ability of pumice substrate and the uptake capacity of the plant Chrysopogon zizanioides. Various research works and experiments were done in both laboratory and full scale on the chromium removal efficiency of constructed wetland, for example Dotro et al., (2011) reported that $90-99 \%$ of chromium removed from tannery wastewater by subsurface constructed wetland with pea gravel substrate and Typha spp.

\section{Comparison between Pumice (test substrate) and Gravel (Control substrate) on the Tanner Wastewater Treatment efficiency of HSSFCW Planted with} CZ

The treatment efficiency of constructed wetland varied according to the type of substrate, plant type, seasonal variation, climatic change and other factors. Even though the plant type is similar in both two beds (control and study), the result of this investigation also varied between the gravel and pumice substrate (Table 4). In this investigation at the first 3 days HRT only BOD $_{5}$ and COD were removed by gravel substrate (89.05\% and $93.82 \%$ ) better than pumice substrate ( $83.36 \%$ and $92.34 \%$ ) but in all other retention time the pumice substrate showed better result than gravel (Table 4 ; Figure 6).

Table 4 TWW Treatment Efficiency of HSSFCW with Gravel and Pumice Substrate and Planted with CZ at Different HRT 


\begin{tabular}{|c|c|c|c|c|c|c|c|c|c|}
\hline \multirow[t]{2}{*}{ Parameters } & \multirow{2}{*}{$\begin{array}{l}\text { Influent conc. } \\
(\mathrm{mg} / \mathrm{l})\end{array}$} & \multicolumn{2}{|c|}{ 3days HRT } & \multicolumn{2}{|c|}{ 5days HRT } & \multicolumn{2}{|c|}{ 7days HRT } & \multicolumn{2}{|c|}{ 9days HRT } \\
\hline & & $\begin{array}{l}\text { Pumice } \\
(\%)\end{array}$ & $\begin{array}{l}\text { Gravel } \\
(\%)\end{array}$ & $\begin{array}{l}\text { Pumice } \\
(\%)\end{array}$ & $\begin{array}{l}\text { Gravel } \\
(\%)\end{array}$ & $\begin{array}{l}\text { Pumice } \\
(\%)\end{array}$ & $\begin{array}{l}\text { Gravel } \\
(\%)\end{array}$ & $\begin{array}{l}\text { Pumice } \\
(\%)\end{array}$ & Gravel (\%) \\
\hline $\mathrm{BOD}_{5}$ & $1641 \pm 373.55$ & 83.36 & 89.05 & 95.49 & 89.58 & 96.42 & 90.96 & 96.30 & 91.85 \\
\hline COD & $6953.33 \pm 339.41$ & 92.34 & 93.82 & 96.76 & 95.81 & 96.91 & 95.94 & 96.62 & 96.33 \\
\hline $\mathrm{NH}_{4}-\mathrm{N}$ & $253.33 \pm 11.6$ & 89.41 & 19.08 & 98.03 & 34.47 & 98.16 & 52.63 & 97.30 & 61.97 \\
\hline $\mathrm{NO}_{3}-\mathrm{N}$ & $116.66 \pm 26.63$ & 90.72 & 66.29 & 100 & 77.15 & 99.68 & 80.86 & 99.51 & 86.00 \\
\hline TN & $650.33 \pm 93.62$ & 93.54 & 68.27 & 98.67 & 86.11 & 99.00 & 90.42 & 98.56 & 88.67 \\
\hline $\mathrm{PO}_{4}-\mathrm{P}$ & $88.06 \pm 40.77$ & 92.81 & 90.92 & 96.55 & 95.20 & 96.97 & 95.68 & 100 & 96.33 \\
\hline TP & $144.53 \pm 20.75$ & 86.39 & 88.47 & 94.79 & 88.93 & 96.17 & 91.47 & 41.97 & 92.16 \\
\hline TSS & $1868 \pm 863.1$ & 94.66 & 95.41 & 95.77 & 95.93 & 95.72 & 96.09 & 96.04 & 96.25 \\
\hline TDS & $5877.3 \pm 2294.77$ & 74.39 & 79.96 & 78.24 & 79.95 & 86.92 & 81.96 & 86.42 & 81.23 \\
\hline $\mathrm{TCr}$ & $18.33 \pm 6.66$ & 95.20 & 96.40 & 98.36 & 97.27 & 98.91 & 97.44 & 98.09 & 97.27 \\
\hline
\end{tabular}

The result between the study and control bed was tested using Two-Sample t-Test, the result showed that significantly differ at $95 \%$ confidence interval, $p$-value $=0.01$ and hence, this substrate can be useful for the treatment of high strength wastewater in horizontal subsurface constructed wetland better than the conventional gravel substrate. Chromium removal efficiency of pumice substrate was better than gravel at all hydraulic time except the first three days that pumice achieved $95.2 \%$ while gravel achieved $96.4 \%$ (Table 4 and Figure 7 ).

The Plant Biometry and Chromium Uptake Capacity of CZ in Gravel and Pumice Substrate Beds

The biometry data of the plant Chrysopogon zizanioides was analyzed for both gravel and pumice substrate. The result showed that the growth of the plant at the sixth month above the ground in $\mathrm{cm}$ was 58.66 and 113.33 and below the ground was 43.33 and 24.33 in gravel and pumice substrate bed respectively. The plant dry weight also indicate that $77,130.8 \mathrm{gm}$ above ground and $80,89 \mathrm{gm}$ below the ground in gravel and pumice substrate respectively (Table 5). The chromium uptake capacity of the plant in both substrate beds was evaluated and revealed that, the plant below the ground uptake more chromium than above the ground that was $(8.88,36.62 \mathrm{mg} / \mathrm{kg}$ ) and $10.24,39.72 \mathrm{gm} / \mathrm{kg})$ in gravel and pumice substrate bed respectively (Table 5).

Table 5 Biometry Data of Chrysopogon zizanioides in Gravel and Pumice Substrate Bed

\begin{tabular}{|lllllll|}
\hline Substrate & \multicolumn{3}{c|}{ Above Ground } & \multicolumn{4}{c|}{ Below Ground } \\
\cline { 2 - 7 } & Length $(\mathrm{cm})$ & Dry weight $(\mathrm{gm})$ & Cr Uptake $(\mathrm{mg} / \mathrm{kg})$ & Length $(\mathrm{cm})$ & Dry weight $(\mathrm{gm})$ & Cr Uptake $(\mathrm{mg} / \mathrm{kg})$ \\
\hline Gravel & 58.66 & 77 & 8.88 & 43.33 & 80 & 36.62 \\
\hline Pumice & 113.33 & 130.8 & 10.24 & 24.33 & 89 & 39.72 \\
\hline
\end{tabular}

Based on the result found from the biometry data, The Cr bioaccumulation factor (BAF) and Translocation factor (TF) of Chrysopogon Zizaniodes plant species was estimated, (as a method described by Baker, et. al., 2000 and Shanker et al., 2004):

$$
\mathrm{BAF}=\underline{m g \underline{C r} / k g d w} \underline{\text { plant }}
$$

Translocation factor of $\mathrm{Cr}$ was also calculated as:

$$
\begin{aligned}
& T F=m g \underline{\mathrm{Cr} / \mathrm{kg} d w \text { above ground }} \\
& \text { mg Cr/kg dw below ground }
\end{aligned}
$$

Therefore BAF of this plant were above the ground $\left(0.48,0.56 \mathrm{Lkg}^{-1}\right)$ and below the ground $\left(1.99,2.17 \mathrm{Lkg}^{-1}\right)$ in gravel and pumice substrate beds respectively. Whereas TF were $(0.24$ and 0.26$)$ in gravel and pumice substrate bed respectively. Plants with more BAF and TF values can remove metals like chromium from the wastewater in the constructed wetland that may be due to the harvesting the areal part of the plant removes chromium 
from the bed. Plant species with high capacity to translocate chromium from below the ground to above the ground enhances absorption of chromium from the constructed wetland bed (Skiffington, et al., 1976; Perk, 2006). Translocation can reduce again chromium concentration and hence that reduce toxicity potential of the metal ions to the root.

\section{Conclusion}

Modjo tannery wastewater characteristics was very high strength wastewater with different hazardous pollutants. The bioaccumulation and translocation factor of Chrysopogon zizanioides were greater in pumice substrate bed than the gravel which means that this plant can remove more chromium in pumice media than gravel one. The tannery wastewater treatment efficiency of pumice substrate was better than gravel substrate.

Horizontal subsurface flow constructed wetland with pumice substrate and Chrysopogon zizanioides plant species has a potential to treat high strength tannery wastewater by different mechanisms including adsorption, filtration, microbial activities and plant uptake. Therefore the use of such kind of constructed wetland with locally-available low-cost substrate and potential plant type may contribute to the low technology solution for sustainable industrial wastewater management in ecofriendly manner.

\section{Declarations}

\section{List of abbreviations}

APHA: American Public Health Association; BOD: Biological Oxygen Demand; COD: Chemical Oxygen Demand; DO: Dissolved Oxygen; EPA: Environmental Protection Authority; ES: Effective Size; FAAS: Flame Atomic Absorption Spectrophotometer; HRT: Hydraulic Retention Time; HSSFCW: Horizontal Subsurface Flow Constructed Wetland; TSS: Total Suspended Solids; TWW: Tannery Wastewater; UC: Uniformity Coefficient; UNIDO: United Nations Industrial Development Organization;

\section{Ethics approval and consent to participate}

Not applicable

\section{Consent for publication}

Not applicable

\section{Availability of data and materials}

The dataset and materials used for this manuscript is available and can be shared whenever necessary. Data was generated by the author from the field substrate and plant sample collection, Constructed wetland design, construction and laboratory analysis.

\section{Competing interests}

The authors declare that they have no competing interests

\section{Funding}

The first author is grateful to Dilla and Addis Ababa University in supporting for expenditures during laboratory analysis.

\section{Authors Contribution}

All authors have made an essential intellectual contribution to this study. MBA designed the study, conducted the experiments, Collected, analyzed and interpreted the data and wrote the manuscript. SLA supervised the experiment, provided comments and suggestion for the whole work. MMK supervised and provided pertinent comments and suggestion on the manuscript. All authors read and approved the final manuscript.

\section{Acknowledgements}

The principal investigator would like to thank Dilla and Addis Ababa University for financial support

\section{Authors' information}

Mekonnen Birhanie Aregu is Assistant professor of Environmental health, school of public health, college of health science and medicine, Dilla University. He has given Public health, Environmental health science and technology courses and also contribute in community services and problem solving applied research activities and published several articles in the internationally peer reviewed journals. He is also a senior consultant in environmental health, waste management and emission control.

Seyoum Leta Asfaw (PhD) is an Associate professor of environmental pollution and sanitation stream, Center for environmental sciences, Addis Ababa University. He has given various courses in the stream. He is also supervising and monitoring several PhDs and MSc students in the areas of 
environmental biotechnology, wastewater treatment and water quality studies, waste to energy (resource recovery and climate change mitigation and adaptation studies), bioremediation, phytoremediation, microbial ecological studies, environmental sanitation. He has published several peer reviewed papers in different international reputable journals. Currently, he is also executive Director for Horn of Africa Regional Environmental Centre and Network (HOARECN).

He has more than 20 years of experience in environmental science and technology studies and management. He had also been a regional program manager for the Bio-resources innovation network for Eastern Africa development. He has also been the principal investigator for a number of research projects such as "Development of innovative technologies for the sustainable treatment of high strength wastewater in East Africa", a regional research program involving Ethiopia, Kenya, Tanzania and Uganda funded by Sida. He developed an innovative, integrated pilot technology for the treatment of agro-process wastewater, generating biogas, biofertilizer, and clean water at Modjo Tannery, Addis Ababa, Ethiopia.

Professor Mohammed Mazharuddin Khan (PhD) is a professor of Environmental Science at Center for Environmental Sciences, Addis Ababa University. He is the CHARLES DARWIN GOLD MEDAL was conferred on the $27^{\text {th }}$ day of June, 2009 towards the contribution made in the field of Life Science by International society for Ecological communication at Vinoba Bhave university, Hazaribagh, Jharkhand, India. He has given several courses like Botany, Biotechnology, Environmental sciences, Ecology, Microbiology, and Environmental Microbiology at postgraduate and undergraduate level. $\mathrm{He}$ is also a founder of different organizations, moreover he is a member of more than eight international professional associations and societies and served in different positions. Professor Khan has published several internationally peer reviewed papers.

\section{References}

Abinaya, S., Saraswathi, R., Rajamohan, S. and Mohammed S.A.M. (2018): Phyto-remediation of total dissolved solids (TDS) by Eichhornia Crassipes, Pistia Stratiotes and Chrysopogon

Zizanioides from second stage RO-Brine solution, Res. J. Chem. Environ., 22 (5): 36-41.

APHA (2005): Standard Methods for the Examination of Water and Wastewater, $21^{\text {st }}$ edn.

American Public health association, Washington.

Arasappan, S. and Kalyanaraman, R. (2015): Characterization of Physicochemical Parameters and heavy metal Analysis of Tannery Effluent.Int.J.Curr.Microbiol.App.Sci 4(9): 349-359.

Asamudo, N. U., Daba, A.S., and Ezeronye, O.U. (2005). Bioremediation of textile effluent using Phanerochaete chrysosporium. Afr. J. Biotechnol. 4(13): 1548-1553.

Assefa Wosnie, Ayalew Wondie (2014): Bahir Dar tannery effluent characterization and its impact on the head of Blue Nile River.Afr. J Environ. Sci. Technol 8 (6):312-318.

Babel, S. and Kurniawan, T.A. (2003): Low-cost adsorbents for heavy metal uptake from contaminated water: A review, J. Hazard. Mat. , 97:219-243.

Baker, ATM. Mcgranth, Reeves, RD. and Smith, JAC. (2000): Metal Hyper Accumulator Plants. A review of the Ecology and Physiology of Biochemical Resource for Phytoremediation of Contaminated Soil and Water: PP.85-107.

Catherine, M., Sylvia, C., John, W., Elias, T. (2006): Phytoremediation of chromium by model constructed wetland, Bioresource Technology 97: 1767-1772.

Dotro, G., Larsen, D., Paul, P. (2011): Preliminary evaluation of biological and physical chemical chromium removal mechanisms in gravel Media used in constructed wetlands. Water Air Soil Pollut. 215: 507-515.

EEPA (Federal Environmental Protection Authority of Ethiopia) (2003): Standards for industrial pollution control in Ethiopia, Part Three: Standards for Industrial effluents. ESIS project 
US/ETH/99/ 068/ETHIOPIA, EPA/UNIDO, Addis Ababa.

Kadlec R. H., and Knight R. L. (1996): Treatment Wetlands. Lewis Publishers, Boca Raton, FL.

Kadlec, R.H., Wallace, S. (2009): Treatment Wetlands, second ed. Boca Raton: CRC press, Boca Raton, Florida, USA.

Kawser, A.M.d., Monika, D., Monirul, I.M., Mosammat, S.A., Shahidul, I. and Muhammad A.A. (2011): Physicochemical Properties of Tannery and Textile Effluents and Surface Water of River Buriganga and Karnatoli, Bangladesh, World Applied Sciences Journal 12 (2): 152-159, ISSN 1818-4952.

Kivaisi, A. K. (2001): The potential for constructed wetlands for wastewater treatment and reuse in developing countries: A review. Ecological Engineering, Vol.16.

Masoud Moradi, Lida Hemati, Meghdad Pirsaheb and Kiomars Sharafi, (2015). Removal of Hexavalent Chromium from Aqueous Solution by Powdered Scoria-Equilibrium Isotherms and Kinetic Studies, World Applied Sciences Journal 33 (3): 393-400.

Nese and Ennil (2004) Nitrate removal from aqueous solution by adsorption onto various materials, Journal of Hazardous Materials, B112: 155-162.

Perk, M.V.D. (2006): Soil and Water Contamination: From Molecular to Catchments Scale. London; JK.

Reddy, K. (2004): Phosphorus Cycling in Wetlands Associated with Agricultural Water Shades. Nutrient Management in Agricultural Watersheds-A wetland Solution- 'A symposium conducted at Teargases Research Center, Johnstown Castle, Cowexfored, Ireland 24-25.

Seyoum Leta, Fassil Asefa, Gunnel, D. (2003): Characterization of tannery wastewater and assessment of downstream pollution profiles along ModjoRiver in Ethiopia, Ethiopian Journal of Biological Sciences 2 (2): 157-168.

Shanker, A.K., Djanaguiraman, M., Sudhagar, R., Chandrashekar, C.N. and Pathmanabhan, G. (2004): Plant Science. 166:1035.

Sivakumar, P., Kanagappan, M. and Sam M.D.S. (2015): Physicochemical Characteristics of Untreated Effluent from Tannery Industries in TamMil Nadu: A Comparative Study, Int J Pharm Bio Sci., 6(1): (B) 446-451.

Skeffington, R., Shwery, PA., Peterson, PJ. (1976): Chromium Uptake and Transport in Barely Seedlings (Hordeum vulgare L.). Plantrta (Ber) 132:209-214.

Stottmeister, U., Wiebner, A., Kuschk, P., Kappelmeyer, U., Kastner, M., Bederski, O., Muller, R.A., Moormann, H. (2003): Effects of plants and microorganisms in constructed wetlands for wastewater treatment. Biotechnol. Adv. 22:93-117.

Suthanthararajan, R., Ravindranath, E., Chits, K., Umamaheswari, B., Ramesh, T., Rajamam, S. 
(2004): Membrane application for recovery and reuse of water from treated tannery wastewater, Desalination 164:151-156.

Tadesse Alemu and Seyoum Leta (2015): Evaluation of selected wetland plants for removal of chromium from tannery wastewater in constructed wetland, Ethiopia.A J Environmental science and technology 9 (5): 420-427.

Tadesse Alemu, Eshetu Lemma, Andualem Mekonnen, Seyoum Leta (2016): Performance of Pilot Scale Anaerobic-SBR System Integrated with Constructed Wetlands for the Treatment of Tannery Wastewater, Environ. Process. 3:815-827, DOI 10.1007/s40710-016-0171-1.

Tamal, M., Dalia, D., Subhasis, M., Siddhartha, D. (2010): Treatment of leather industry wastewater by aerobic biological and Fenton oxidation process, J Hazardous Materials180: 204-211.

Tomokin, O. (2000): A Pilot Study on Municipal Wastewater Treatment Using a Constructed Wetland in Uganda. UNESCO-IHE Dissertation, Serious Information J.Taylor \& Francis Engineering, Water and Earth Sciences. www.blakema.nl/series.

Travaini, L.F. and Sipauba, T.L.H. (2012): Efficiency of a constructed wetland for wastewaters treatment, Acta Limnologica Brasiliensia, 24 (3): 255-265.

Truong, P. and Stone, R. (1996): Vetiver grass for landfill rehabilitation: Erosion and leachate control, Report to DNR and Redland Shire Council, Queensland, Australia.

UNIDO (2012): Technical assistance project for the upgrading of the Ethiopian leather and leather products industry, Independent Evaluation Report Ethiopia.

https://www.unido.org/fileadmin/user/Evaluation/Ethiopia_leather_valuation FINAL_report_131302.pdf. Accessed Sep 2016.

Villara, M.M., Domíngueza, E.R., Tackb, F., Ruiza, J.M, Moralesa, R.S., Arteaga, L.E (2012): Vertical subsurface wetlands for wastewater purification, 20th International Congress of Chemical and Process Engineering CHISA 2012, 25-29 August 2012, Prague, Czech Republic, Procedia Engineering 42: 1960 -1968, Available online at www.sciencedirect.com.

Vymazal J. (2010): Constructed wetlands for wastewater treatment: five decades of experience Environmental Science and Technology, vol. 45.

WHO (1996): Guidelines for drinking water quality, vol 2: Health criteria and other supporting information, Geneva.

Xia, H., Liu, S. and Ao, H. (2000): Study on purification and uptake of garbage leachate by vetiver grass., In: Proc. of the 2nd International Conference on Vetiver, Thailand.

\section{Figures}




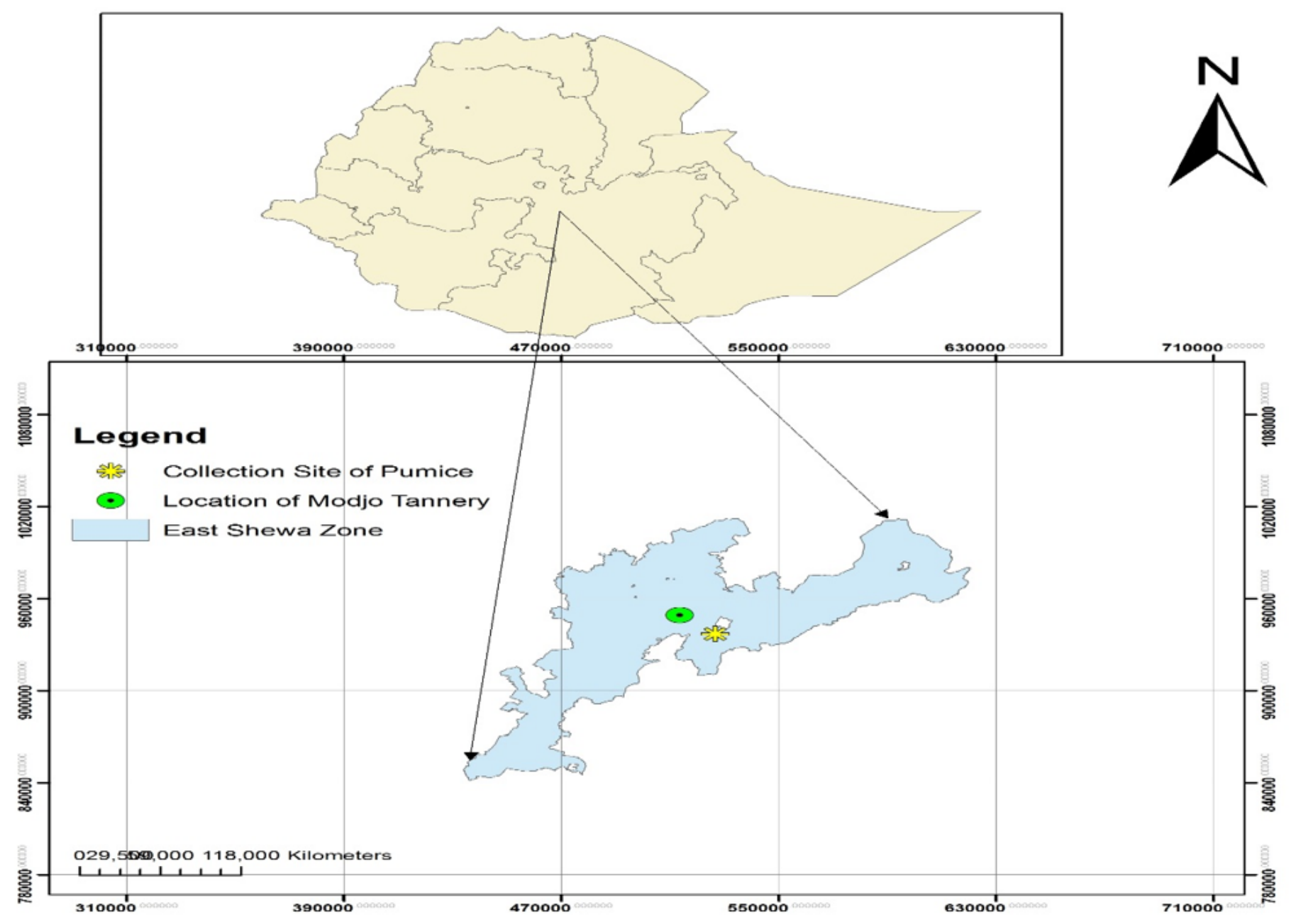

Figure 1

Map of Study Area and Location of Pumice

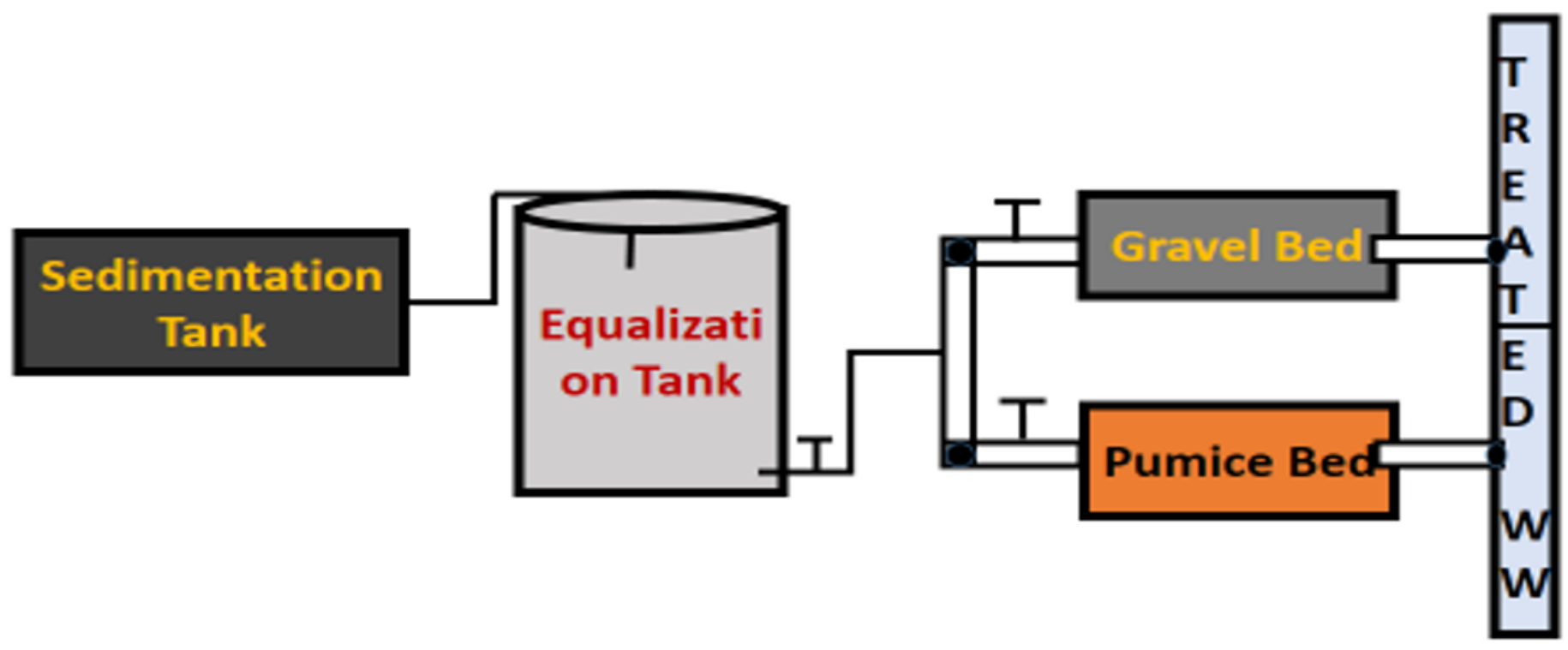

Figure 2

Schematic Diagram of the Horizontal Subsurface Constructed Wetland 


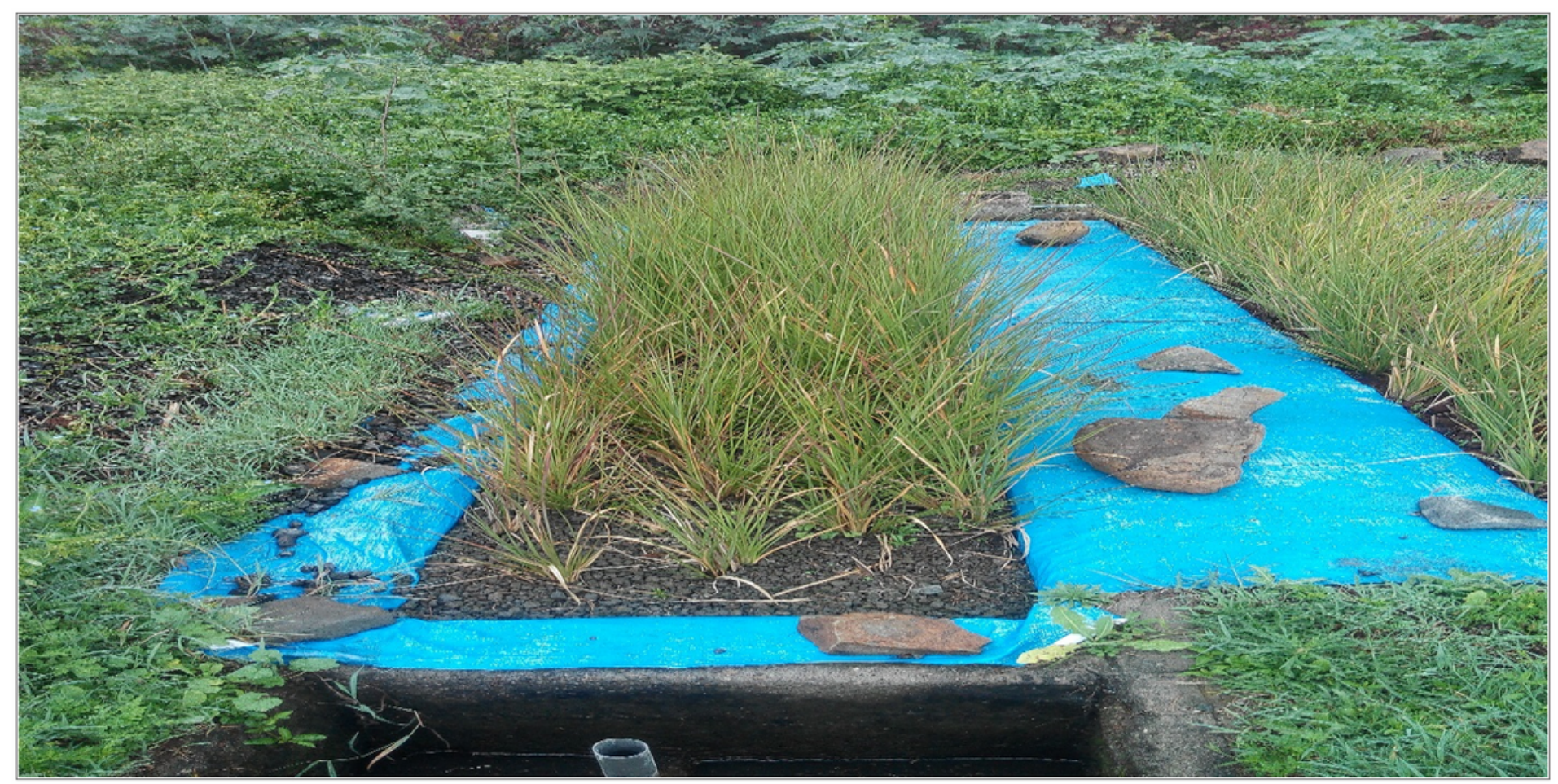

Figure 3

Pumice and Gravel substrate bed (Photo by Mekonnen Birhanie, 2018)

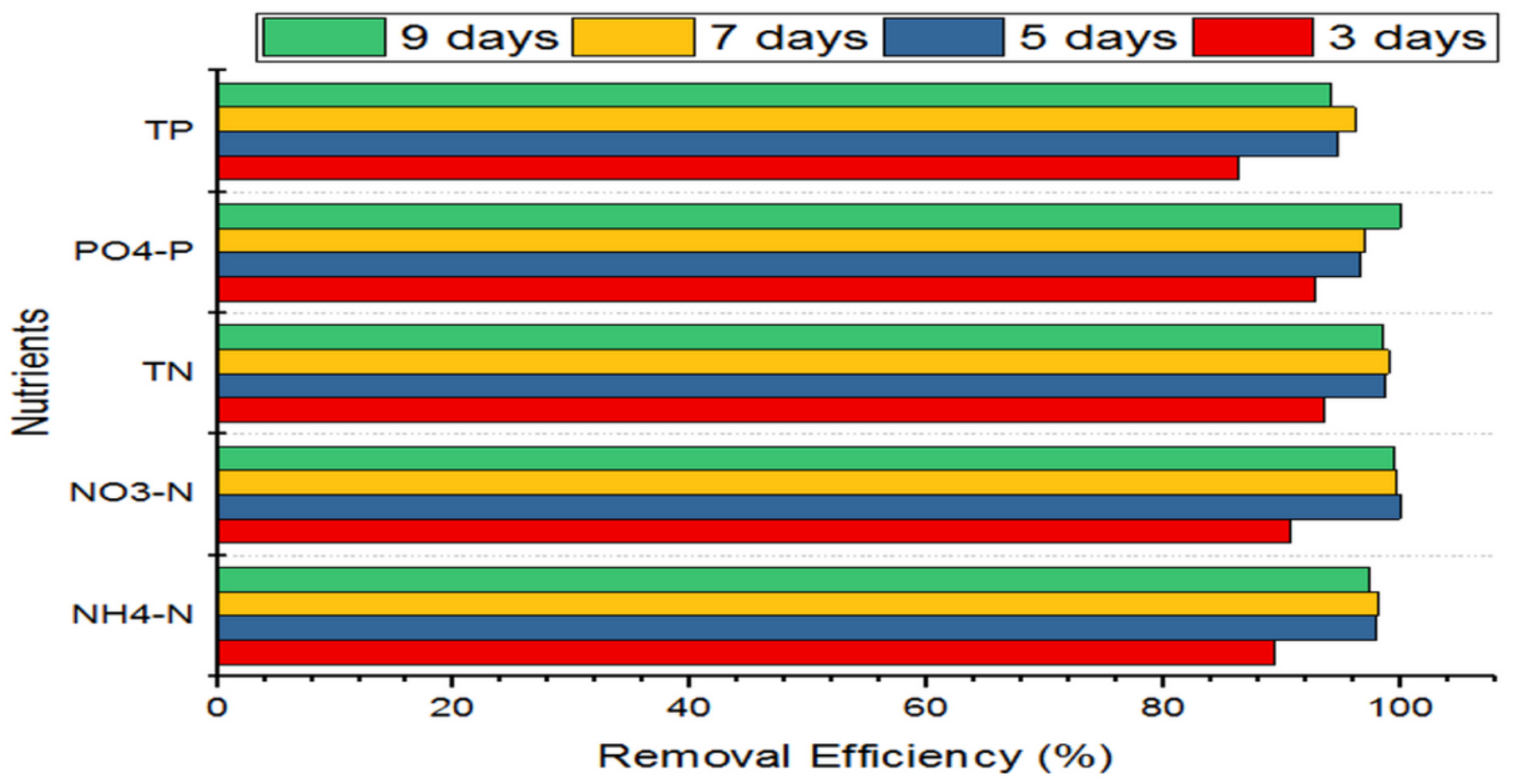

Figure 4

Nutrient Removal Efficiency of Pumice Substrate Planted with CZ at Different HRT 


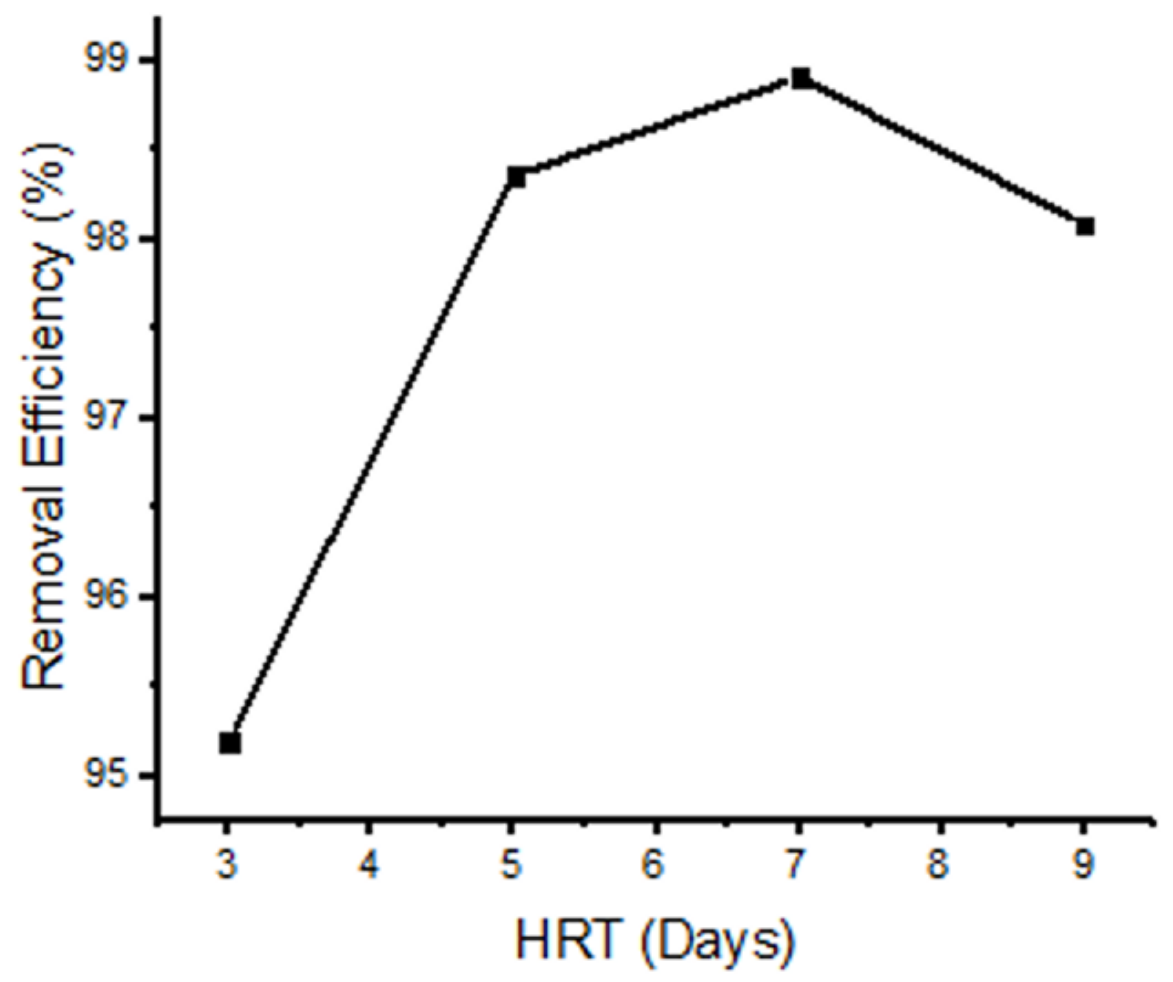

Figure 5

Chromium Removal Efficiency of HSSFCW with Pumice Substrate

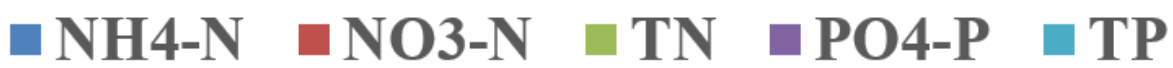

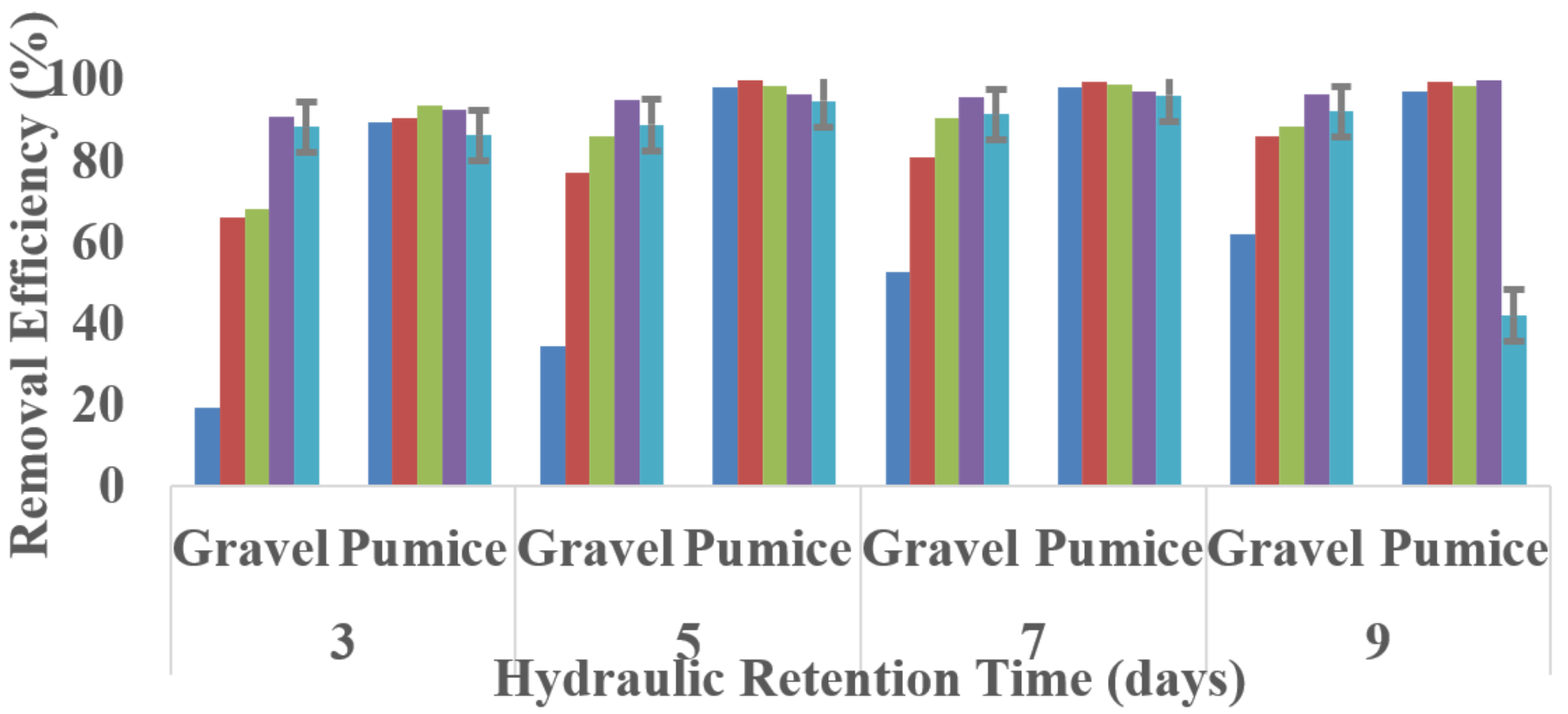

Figure 6

Nutrient Removal Efficiency of HSSFCW with Gravel and Pumice Substrate 


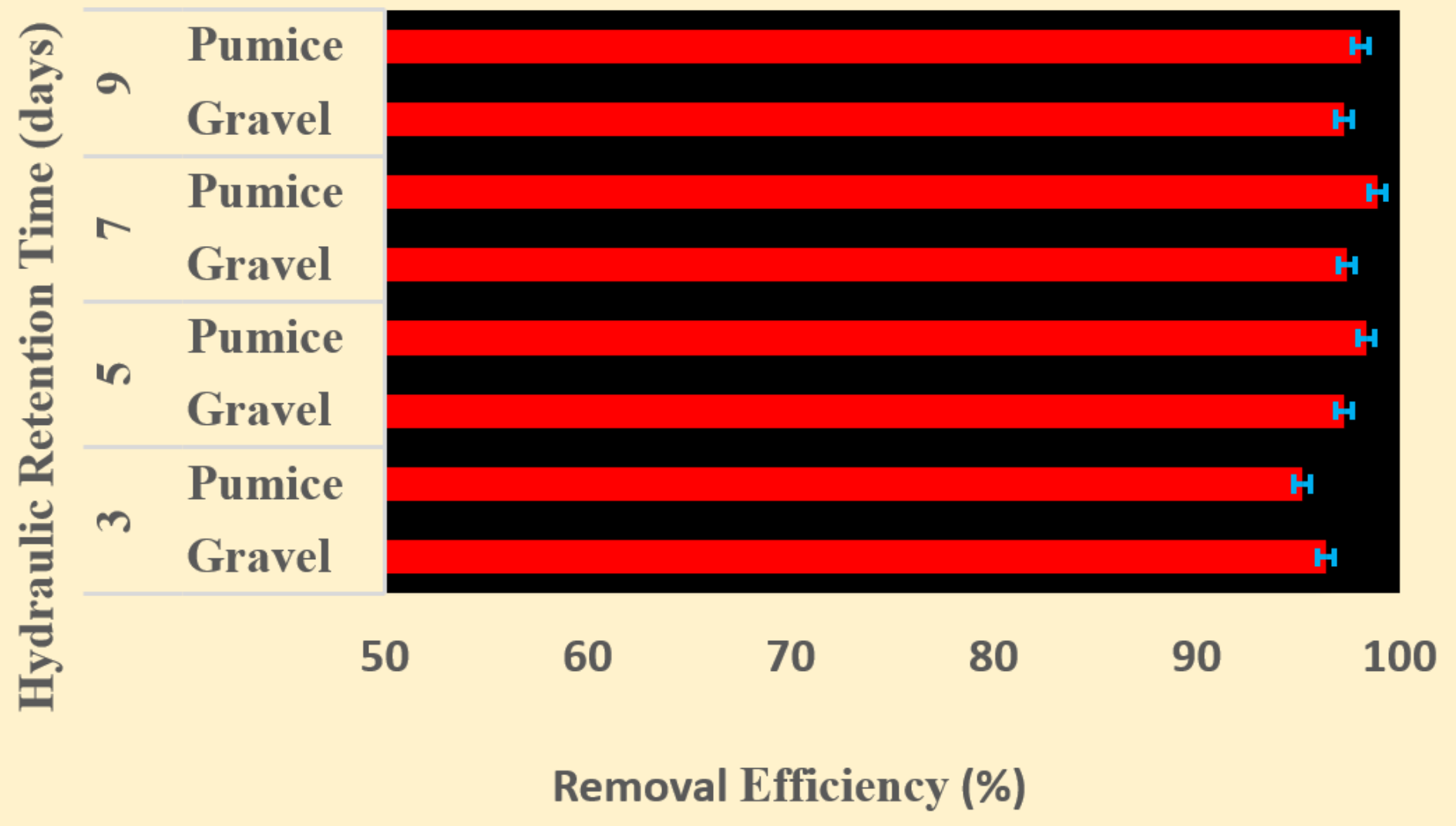

Figure 7

Chromium Removal Efficiency of HSSFCW with Gravel and Pumice Substrate 